Asian Studies International Journal

ISSN: 2279-1949

Available Online at www.asianstudies.info

Volume:1; Issue No 1; January 2021; Page No.17-23

DOI: https://doi.org/10.47722/ASIJ.1003

ICRD

Research Article

\title{
SPECIAL ECONOMIC ZONES, THE BELT AND ROAD INITIATIVE AND THE FUTURE DEVELOPMENT OF KACHIN STATE
}

\author{
Dr John Walsh
}

School of Business \& Management, International Business, RMIT Vietnam

\begin{abstract}
A R T I C L E I N F O ABSTRACT

Article History:

Kachin individuals and organizations operate within a dense and complex web of domestic and cross-border links that integrate them into a series of network relationships with communities around them. Problems with governance, lack of ability in terms of nation-building and the prevalence of high-risk economic activities have been some of the factors that have constrained economic growth for the State, which represents a similar situation for other spatially outlying people of Myanmar such as the Naga and the Chin. Some limited attempts have been made to create coherent economic organizations so as to help to promote peaceful governance of the land and the needed replacement of opium growing offers an opportunity for cash crop production and exporting that has been successfully exploited elsewhere. However, limitations to the labour force and to resource management capability mean that endogenous economic development is a very limited prospect. An available alternative to internal development is to be the recipient of externally imposed developmental initiatives. Notable among these initiatives is an industrial park or a special economic zone to be built by Chinese capital, such as the proposed Kanpiketi border park. Such an initiative would take its place alongside existing and proposed Chinese projects in Kyaukphyu, Yangon and elsewhere, which have achieved mixed levels of success. Is it possible that such projects, as part of China's Belt and Road Initiative outreach program, could offer meaningful and sustainable improvement to the standard of living of people in Kachin State? If so, what would be the impact of a new mode of economic activity on existing patterns of Kachin ways of life? This paper uses a case study approach rooted in management science to investigate the possibilities of these initiatives with a view to understanding the potential of such changes.
\end{abstract}

Copyright $\bigcirc 2021$ by author. This is an open access article distributed under the Creative Commons Attribution License - NonCommercial 4.0 International (CC BY-NC 4.0) which permits unrestricted use, distribution, and reproduction in any medium, provided the original work is properly cited.

\section{Introduction}

Kachin State is a mountainous, forested region between ethnic Bamar majority Myanmar and China. With its geography and its state-level development goals differing from its neighbours, together with porous borders on either side of which related peoples feel more kinship with each other rather than the state in which they happen to reside, Kachin State is redolent of the concept of Zomia (Scott, 2009). Yet Kachin people do maintain a number of transnational connections with other parts of the world, notably with the brethren of Baptist believers and with the diaspora of its own people. Some of the relatively limited number of economic activities that do take place on Kachin soil have the potential to link the state more closely with the outside world and, if they could do so, that might make a contribution to Kachin people being able to overcome some of the social ills with which their society is beset, including the spread of narcotics and the risktaking behaviour that accompanies that issue and the issue of warfare and the situation of internally-displaced persons (IDPs) that are produced by fighting and violence. 
Unfortunately, those activities which do cross borders - notably the jade and opium trades - are those which are often kept out of the notice of the state and do little to promote development indeed, they are typical of the forces of maldevelopment which have blighted the lives of so many people around the world (Amin, 2011).

The purpose of this paper is to consider, from a business management perspective, what are the prospects for Kachin State's economic development under current conditions. It considers the possibility of endogenous development with the contribution of crop substitution and the development of existing business and commercial activities. It also considers the potential role of a special economic zone (SEZ), presumably paid for by Chinese capital and the implications this would have for inter-state relations in the region. It also considers the possible role of non-standard economic development such as casino capitalism in a region which is close to being considered a semiautonomous zone. A number of semi-autonomous zones in the Greater Mekong Subregion have been extensively colonised by Chinese capital (and this extends to the northern capital of Mandalay) and migrants. For example, tissueculture bananas have transformed large areas of Kachin land into monocropped plantations with both products and profits intended for relocation across the Chinese border. At least some of the land involved appears to have been expropriated from IDPs (Soe \& Dunant, 2020). Other areas have become outposts of casino capitalism, beyond the effective reach of the state (Walsh, 2016). This is one expression of negative social and economic development which it is possible could occur. Capitalism, infamously, is a form of creative destruction and the new forms of activity it stimulates may not be beneficial to all stakeholders.

\section{Context of Kachin State Economic Development}

Kachin State agriculture is characterised by the rice paddy format typical of mainland Southeast Asia and by the elevated heights of much of the territory. Elevation has a close relationship with the type of land cover evident in particular locations and with a direct implication for the kind of agriculture that may be practiced there. There are, in fact, five different types of forest present, which are tropical evergreen rain forest; sub-tropical hill forest; warm-temperate rain forest; cool-temperate rain forest and rhododendron-silver fir forest. There is potential for exploitation of these areas for different forest products, although there exist difficulties in terms of infrastructure and, in particular, in access to local and regional markets as a result of difficult transportation.

Table 1: Principal Statistics for Kachin State; source: collated by the author from various sources.

Size: $89,041 \mathrm{~km}^{2}$

Population: 1.7 million (estimated)

Capital City: Myitkyina

Other major cities: Bhamo, Mohnyin, Putao

GDP per capita (Myanmar): US\$6,300 (estimated, 2017). Much lower for Kachin State.

Main economic activities: agriculture, jade and gem mining, opium production. Potential for hydroelectricity.

In other parts of Myanmar, notably the Shan states to the south, hilly areas betoken tea cultivation as both a cultural marker and also a potential cash crop. These days, tea of various categories is marketed through contemporary brands in retail outlets in the country and also in export markets. There were once plans to grow tea on a significant basis, albeit plans that were never brought to fruition. However, tea has never become an important source of cultural production for Kachin people and it has not played a significant role in the production and reproduction of social relations. Consequently, a potential avenue of economic development that might have benefited at least some stakeholders in Kachin society was not travelled. Instead, the focus has been on rice paddy for subsistence agriculture.

"By area, the main crop in Kachin State is rice paddy - about 660,000 acres in 2010-11, up from 431,000 acres in 2005. Other crops with about a tenth as much area each are peanuts, fruits, vegetables and rubber. There are many other crops with much smaller areas planted. Some of these are grown on land not used for rice and some on rice land wen monsoon rice crops are not being grown. 
There might altogether and generously be 900 thousand acres that are cultivated by smallholders (Dapice, 2016)."

According to the 2014 Population Census, there are around 200,000 farming households in the State, with approximately one million rural inhabitants and an average farm size of 4-5 acres (ibid.). It has been estimated that rice paddy production could be doubled if all advanced techniques and inputs available were to be introduced. Owing to the small size of these farms, profitability is low even when cash crops are grown and there are many problems with access to markets and to inputs. These are long standing problems and help explain why Kachin State did not receive the dubious benefits of colonial economic development by being integrated more closely with core-periphery economic systems. For example, a conventional colonial developmental tactic would be logging of trees, especially hardwoods, which could be sent by truck to Myitkyina and thence southwards by barge to the markets of central Myanmar.

The lack of colonial-era economic development contributed to something of a vacuum as the people of the hills and mountains were left outside the main economic system of the region. This exacerbates the opium problem because alternative opportunities are reduced as a result. This is evident in the country as a whole since World Bank figures recently released show that poverty rates remain at $32.1 \%$ in 2015 , albeit that is significantly down on previous years. Although the government has begun to invest more strongly in rural areas to promote rural development and connectivity, it is going to take some years before the results will become visible (Choragudi, 2018). To basic agriculture should be added the presence of substantial resources of jade and other natural resources which can be extracted for considerable resale value. However, the markets for these products are largely controlled by Chinese interests and the conditions on working in locating the gems are notoriously dangerous. For example, Long-distance truck drivers, people working on fishing boats or scavenging from jade or gold mines are among those vulnerable to drug addiction in northern Myanmar. In the north of the country, where the reach of the central government is comparatively limited, workers may be partly paid in opium in recognition of the fact that their working lives are so benighted and subject to risk (Walsh, 2019).

\section{Dealing with the Drugs Issue}

The drugs issue in Kachin State is endemic and prevalent and so complex in its combination of causes and effects as to merit the term of being a 'wicked problem,' that is, it is a problem (or set of problems) that "... are ill-defined; and they rely upon elusive political judgment for resolution. (Not 'solution.' Social problems are never solved. At best they are only re-solved over and over again.) (Rittel \& Webber, 1973)." Drug usage is wicked in this sense because it is not clear what should be done about them, in a world in which zero tolerance of drug usage does not seem to be a pragmatic response since, according to research, it provides many incentives to hide what is happening. It can represent a significant deterrence effect (Mekay \& Pacula, 1999) but, in complex societies, can become intertwined with discriminatory action against people with minority or marginalised status and makes no meaningful provision for people who, for whatever reason, fall foul of the laws (Skiba, 2010). Overall, opium production in Kachin State occupies some 3,900 ha or approximately $12 \%$ of the national total. Land use has actually increased slightly in recent years, which contradicts the national level reduction which may in part be due to the reduction in farmgate prices of $51 \%$ for dry opium over the past four years and the greater use of synthetic drugs like heroin (UNODC, 2020). It is estimated that there are some 83,000 drug addicts in the border regions on Kachin State and they suffer from an HIV transmission rate of $28.5 \%$ (Eleven Myanmar, 2019).

Previous research (Lomethong \& Walsh, 2019) has indicated that rehabilitation of victims of drugs usage and management of issues arising from the trade will depend on, at least to a certain extent, the feasibility of substituting a different cash crop for opium and helping farmers bring the crop to sale in local markets. One important aspect of farming opium for a second harvest is that the opium dealers offer to come to the farmgate and pay in cash a reasonable price for the ready crop. This is an important incentive and represents a significant impediment to normal market actions which must be considered. It can be approached through a combination of organization of farmers, so that they can work together in a farmers' production group or similar form of cooperative and aim to gain economies of scale. It also requires co-ordination of activities with respect to the availability and uses of inputs 
in agricultural production. Third, there is a need to integrate production of the substitute crop or crops into value chains and supply chains so as to add value to basic production and, thereby, reduce the risk of volatility of prices. There has been some success in this respect in terms of coffee and cabbage production in neighbouring Thailand but, where success has been achieved in these cases, it has required some forms of subsidy from government funds.

\section{Special Economic Zones}

The Kachin people occupy a position between China and the historical Burmese state. Occupying a peripheral role on account of geography and ethnic difference, the land of the Kachin is a form of borderland (Anzaldua, 2012) - that is, land which is not just the border but a zone of uncertainty, being liminal in the sense of not being part of the principal states to north and south. The borderlands concept suggests lack of agency, while the Zomia concept (Scott, 2009) suggests at least some measure of agency. If it is necessary to make a decision between these two alternatives, then it suggests the necessity of connectivity so that the degree of agency that might exist could be measured. However, the Kachin have historically lacked this connectivity - they are remote on the hills and mountains, their language and customs are different, they followed a different religion and, as has been observed, the tongue of Pali (and its influence) is stilled above an altitude of 500 metres. As a result, the Kachin did not occupy the same role in written Chinese historical methods that other peoples - the Shans and other wandering Tai tribes, for example - had done.

However, the Open Door policy made formal sector activities more possible and, in due course, Chinese government agencies and corporations became involved in large-scale infrastructure projects serving state-level developmental goals. A principal example of this is the Kyaukphyu deep-sea port, special economic zone (SEZ) and oil and gas pipeline leading to Kunming. These developments required the Chinese government to establish more stable relations with Myanmar. Recently, Daw Aung San Suu Kyi took part in a meeting with Chinese officials to sign a memorandum of understanding about cooperation in various aspects.

- In this regard, the Chinese government has several priorities having an impact on the
Kachin people and on the production and trafficking of drugs:

- Stability and peace. Development requires the rule of law and this is compromised by the presence of cross-border fighting and of refugees. The Chinese state will take what it deems to be suitable actions to prevent the former and strengthen the border to prevent the mobility of the latter. There have been some setbacks to this policy but the state has persisted;

- Enforce anti-drugs policies throughout China. Notwithstanding the current issues, the modern Chinese state has suffered greatly from the presence of narcotics and its government (despite some individual cases of lawlessness) is determined they should be eradicated completely. This policy is inflexible and calls for occasional cross-border activities:

- Enforce a Chinese model of development which can be at odds with those employed in cross-border actions. This also requires border stability and this is to be achieved, at least in part, by the imposition of market discipline through the creation of SEZs at Sittwe and the semi-formal SEZ at Jiegao. Given potentially lucrative alternative opportunities, it is expected that opium farmers (those who are not forced to change their lifestyles) will be encouraged to move into other trades.

One of the ways in which this might be achieved is through the creation of a special economic zone (SEZ) and, indeed, there have been rumours of the creation of the creation of a Kachin economic development zone, also known as the Namjim Industrial Zone, $25 \mathrm{~km}$ away from the capital Mytikyina, resulting from an $\mathrm{MoU}$ signed between the two countries and with the involvement of the Yunnan Tengchong Heng Yong Investment Company (YTHIC) (Lwin, 2019). China has successfully built a much larger SEZ at the port of Kyaukpyu, which is attached to twin pipelines intending to take oil and gas across country all the way to Kunming, the capital of Yunnan province, thereby avoiding the Malacca Straits naval chokepoint. However, relations between the two countries have not been strong enough over the past couple of years to enable the pipelines to have been able to enter full operation. Even so, Yunnan Province has become identified as a pole in the economic development of southern neighbours through the creation of such controlled spaces (e.g. InKunming, 2017). As 
China has made these advances, it has also brought pressure to bear on the Myanmar government to make peace with Kachin and other rebels so as not to endanger the investment or, being more graceful, so that more people could benefit from the development (Ji, 2012).

This is not the first attempt to bind together the two countries with the creation of a crossborder zone. The China-Myanmar Economic Corridor (CMEC) calls for a series of SEZs that would link the border with the Kyaukpyu project, including zones in Shan and Rakhine States as well as Kachin State. Three linked zones were due to be built in Muse Township in Shan State and Chinshwehaw in Laukkai Township, also in Shan State but a part of the Kokang Self-Administered Zone. The Kachin State zone would be built at Kankipeti (Lwin, 2020). However, the modern conception of the SEZ includes externallyinvested residential, health, education and leisure facilities aimed at improving the quality of life of the investing manufacturing of production facility, as part of long-term investment projects which take advantage of resource-seeking (i.e. low labour and rent costs) activities, perhaps with a bird's-eye view at achieving market-seeking opportunities. In these cases, governments and investors would work together to provide the necessary electricity, water and transportation infrastructure necessary to support a long-term investment (Walsh, 2013). Governments are motivated by the prospect of direct employment, technology transfer and spin-offs of best practices that are offered by inwards foreign direct investment (FDI). However, the various areas proposed are remote and lacking in basic infrastructure to the extent that it is hard to imagine sophisticated economic activities being based there. Such activities that are possible there are likely to feature extensive use of low cost labour for production of relatively low valueadded products based on agro-production or basic commodities presumably to be marketed in south China. A trade flow of this sort already exists, often one which varies from formal to informal based on location- and time-specific factors, in products such as bananas, pumpkins and cosmetics made from inca inchi nuts.

An additional option is to use the River Sheweli, which flows from China through Kachin State before joining with the Ayeyarwaddy and passing through Mandalay on the way to the south. This would offer a potentially useful trade route for Kachin State producers and dealers, since the Ayeyarwaddy is already an important trade link for China and, according to some sources, might replace the projected high-speed train project as a central thoroughfare (Lintner, 2020). There is anecdotal evidence that the cancelling of a dam planned for the Sheweli has placed the Myanmar government under the obligation to more helpful with opening a new route. However, the border is currently closed altogether to try to prevent the further spread of the COVID-19 coronavirus. Another possibility is investment by India, where the government seems to have adopted ineffectual Look East campaigns throughout living memory. However, Indian investment at Sittwe or elsewhere are also subject to problematic international relations, particularly at the present time as conflict between India and China in the Himalayas threatens a more dangerous situation still (Safi, Ellis-Petersen \& Davidson, 2020). The Kachin people are unlikely to benefit from Indian investment in such circumstances, not least because of the longstanding claim that, somehow, such a development would bring about a KachinTibetan alliance that would be likely to be poisonous to China in transnational organizations (Paliwal, 2020).

\section{Alternative Forms of Development}

Cross-border relations consisted of both informal means among trading networks and, also, inter- and intra-ethnic networks. These were Kachin or Kachin-related people on both sides of the border then as now and, in general, people recognised the ethnic kinship to be more important than any nationalist identity. Although the Chinese state took steps to strengthen and regularise the border with Burma, certainly moving beyond the feudal tu si system that had been previously enforced, there was little actual technical capacity in the area and resources were insufficient to patrol the considerable expanse of land involved. Kachin people entered a world in which both formal and informal systems coexisted. In the same way today that people crossing borders across the Greater Mekong Subregion (GMS) can effectively choose between regular and irregular means, so too could the Kachin choose to operate in a formal or informal world. This form of cross-border movement makes more possible the form of cash-based leisure industry autonomous zones that are evident in other parts of the GMSR. Numerous 
casino sites dot the rivers that border Myanmar and whose control is said to be in the hands of powerful member of the establishment. The town of Mong La in northern Myanmar close to the Chinese border is well-known for its casinos, since it is illegal to gamble in China but many Chinese people are happy to cross borders in order to take a chance at the activity. Most recently, it has been declared that a new zone will be created in northern Laos that will be linked, via the River Mekong, with autonomy-seeking eastern Myanmar. That the international port thereby created will apparently be controlled by Zhao Wei, a Chinese casino magnate (Strangio, 2020).

Development of this sort is asymmetric and usually unsustainable, since the promotion of para-statal zones seems almost inevitably to lead to crime of one sort or another (or in some cases an inaccurate presumption of criminal activity) and this provokes an intervention by security forces sooner or later. Those who are most vulnerable are usually the workers and employees, whose livelihoods are precarious at the best of times but who lack even the barest support from the rule of law when occupying zones where that rule of law does not reach. The most that could be hoped for such a maldevelopment would be that it would leave some capital in the area which could then be used by some Kachin people for a more useful form of accumulation.

\section{Conclusion}

Globalisation is thought to have brought into contact or, at least, taken steps towards bringing into contact all the places of production and consumption in the world. Imagining the map of the world according to this concept is to imagine it as a series of lines or highways linking those places of production or consumption, with the rest of the world only being part of the global system if they can create some form of connectivity with the emergent and dominant system. This is a variation of the structural dependency model in which membership of the periphery is betokened not by being remote from the core areas but, instead, by lacking connectivity with areas that might be very close but nevertheless unobtainable for many classes of people. Much of Kachin State, according to this schema, is part of the periphery not by virtue of being part of Myanmar, which is not a core area and not because of being peripheral geographically to the Chinese core.
Instead, Kachin State is part of the periphery in that it has few if any points of engagement with the links between the consumption-production dominant axes. To some extent, parts of the State could obtain connectivity through proximity to or membership of spaces which have joined the core: for example, the establishment of an SEZ offers opportunities for stakeholders to make common cause with newly enfranchised members of the core (i.e. by being suppliers to core members, neighbours or employees). In the absence of the coronavirus and with a modicum of good governance, it should be possible to extend connectivity across many parts of the economy and this might help with bringing into the rule of law those activities that are currently outside of it. However, this does not seem likely at the current time, partly because of the coronavirus but also because of problematic international state relations and social relations at smaller scales.

Inevitably, analysis of the sort presented in this paper would be improved (by greater length) if a longer timescale could be adopted and with a wider range of considerations than is possible in this case. It might, more positively, be claimed that there is an opportunity for refinement of the work and claims for its accuracy with a better geographical and historical perspective.

\section{References}

Amin, Samir (2011). Maldevelopment: Anatomy of a global failure, second edition. Pambazuka Press.

Anzaldua, Gloria (2012). Borderlands/La Frontera: The new Mestiza, fourth edition. Iowa City, IO: Aunt Lute Books).

Choragudi, Upendranadh (2018). Inclusive development, Mizzima Weekly (January $4^{\text {th }}$ ), 7(1), 28-9.

Dapice, David (2016). Kachin State development prospects and priorities, Proximity Designs, available at: ash.harvard.edu/files/ash/files/Kachin_state_development_ prospects_\&_priorities_5_13_16.pdf.

Eleven Myanmar (2019, July $\left.4^{\text {th }}\right)$. Kachin States sees rising number of drug addicts, available at: https://elevenmyanmar.com/news/kachin-state-sees-risingnumber-of-drug-addicts.

InKunming (2107). Lincang economic zone: A miniature of China-Myanmar cooperation (March $3^{\text {rd }}$ ), available at: en.kunming.cn/index/content/201703/content_4539444.htm.

Ji, Tsa (2012). Lessons from the Kachin 'development' experience, Kachin Development Networking Group. 
Lintner, Bertil (2020), China's Belt and Road detours downstream in Myanmar, Asia Times (February 22 $2^{\text {nd }}$ ), available at: https://asiatimes.com/2020/02/chinas-belt-androad-detours-downstream-in-myanmar/.

Lomethong, Jen and John Walsh (2019). Management of drug rehabilitation strategies in Kachin State, Optimization: Journal of Research in Management, 11(2), 13-26, available at: http://glbimr.org/optimization-11-2-juldec-2019.pdf.

Lwin, Nan (2019). Deal to be signed for BRI-related economic zone in Myanmar's Kachin State, The Irrawaddy (October $\left.\quad 7^{\text {th }}\right), \quad$ available at: https://www.irrawaddy.com/news/burma/deal-signed-brirelated-economic-zone-myanmar-kachin-state.html.

Lwin, Nan (2020). Kachin State approves Chinesebacked business park in border town, The Irrawaddy (February $27^{\text {th }}$ ), available at: https://www.irrawaddy.com/news/burma/kachin-stateapproves-chinese-backed-business-park-border-town.html.

Mekay, S.L. \& Liccardo Pacula, R. (1999), The effectiveness of workplace drug prevention policies: Does 'zero tolerance' work?' NBER Working Paper, 7383, available at: www.nber.org/papers/w7783.

Paliwal, Avinash (2020), India's connection in Myanmar, Observer Research Foundation (October $7^{\text {th }}$ ), available at: https://www.orfonline.org/expert-speak/indiaskachin-connection-in-myanmar/.

Rittel, H.W.J. \& Webber, M.M. (1973), Dilemmas in a general theory of planning, Policy Sciences, 4, 155-69.

Safi, Michael, Hannah Ellis-Petersen and Helen Davidson (2020). Soldiers fell to their deaths as India and China's troops fought with rocks, The Guardian (June $17^{\text {th }}$ ), available https://www.theguardian.com/world/2020/jun/17/shockand-anger-in-india-after-worst-attack-on-china-border-indecades.
Scott, James C. (2009). The art of not being governed: An anarchist history of upland Southeast Asia. New Haven, CT and London: Yale University Press.

Skiba, R. (2010). Zero tolerance and alternative discipline strategies, National Association of School Psychologists Communiqué, 39(1), 28-30.

Soe, Hein Ko and Ben Dunant (2020), Kachin's plantation curse, Frontier Myanmar (January $17^{\text {th }}$ ), available at: https://frontiermyanmar.netenkachins-plantationcurse.html.

Strangio, Sebastian (2020), Golden Triangle casino baron bankrolls new Mekong river port, The Diplomat (October $14^{\text {th }}$ ), available at: https://thediplomat.com/2020/10/golden-triangle-casinobaron-bankrolls-new-mekong-river-port/.

United Nations Office on Drugs and Crime (UNODC) (2020), Myanmar opium cultivation drops again as the regional drug economy continues to evolve, available at: https://www.unodc.org/unodc/en/frontpage/2020/February/ myanmar-opium-cultivation-drops-again-as-the-regionaldrug-economy-continues-to-evolve.html.

Walsh, John (2016). Casino resorts as micro-para-statal areas in the GMSR: Connectivity and economic development, The Myanmar Journal, 3(1), 21-31, available at:

http://www.komyra.com/bbs/board.php?bo_table=articles\& wr_id $=44$.

Walsh, John (2013). Social policy and special economic zones in the Greater Mekong Subregion, International Journal of Social Quality, 3(1), 44-56.

Walsh, John (2019). Failing drugs war in Northern Myanmar, East Asia Forum (September 21 ${ }^{\mathrm{st}}$ ), available at: https://www.eastasiaforum.org/2019/09/21/failing-drugwars-in-northern-myanmar/.

\section{How to cite this article:}

Walsh J. (2021) 'Special Economic Zones, the Belt and Road Initiative and the Future Development of Kachin State', Asian Studies International Journal, Volume:1; Issue No 1; January 2021; Page 17-23. DOI: https://doi.org/10.47722/ASIJ.1003 